\title{
Features of Modeling the Formation of Teaching Staff Competitiveness
}

\author{
Nina A. Ivanenko ${ }^{1}$, Linar G. Akhmetov ${ }^{2}$, Sergei Y. Lavrentiev ${ }^{3}$, Elena P. Kartashova ${ }^{3}$, Larisa V. Lezhnina ${ }^{3}$, \\ Kseniya A. Tzaregorodtzeva ${ }^{3} \&$ Elmira R. Khairullina ${ }^{4}$ \\ ${ }^{1}$ Kazan National Research Technical University named after A. N. Tupolev, Kazan, Russia \\ ${ }^{2}$ Kazan Federal University, Kazan, Russia \\ ${ }^{3}$ Mari State University, Yoshkar-Ola, Russia \\ ${ }^{4}$ Kazan National Research Technological University, Kazan, Russia \\ Correspondence: Nina Andreyevna Ivanenko, associate professor of Technical College at Kazan National \\ Research Technical University named after A. N. Tupolev, K. Marks Street, 10, Kazan, Tatarstan, 420111, Russia. \\ E-mail: alfkazan@mail.ru
}

Received: January 17, 2015 Accepted: January 29, 2015 Online Published: February 25, 2015

doi:10.5539/res.v7n3p37 URL: http://dx.doi.org/10.5539/res.v7n3p37

\begin{abstract}
The state is interested in the formation of teaching staff competitiveness of both higher and secondary vocational education institutions, as it is associated with solving the problems of training competitive specialists for innovative production, increasing the social efficiency of organizations and institutions, economic recovery of the country. In this regard, this article reveals the specifics of modeling the process of the teaching staff competitiveness formation. Major approaches to the study of this problem were the integrative and milieu approaches, a symbiosis of which allows creating competitiveness of the teaching staff, taking into account the features of college educational environment, involving integration of educational, methodological and research activities of teachers; features of professional and interprofessional interaction between members of college teaching staff with staffs of other educational institutions, scientific research institutes, professional community. Specifics of modeling the formation of college teaching staff competitiveness consist in the set of components proposed by the authors (theoretically-methodological, functionally-targeted, substantive, procedural and productive clusters) and in their contents.
\end{abstract}

Keywords: modeling, competitiveness, teaching staff, integrative and milieu approaches

\section{Introduction}

The relevance of teachers' competitiveness formation is that the developing labor market makes high demands on the specialist. In all spheres of activity such qualities are becoming increasingly important as social responsibility, adequate perception and mobile response to new factors, independence and efficiency in decision-making, readiness for democratic dialogue, socially active action, including protection of one's rights, the ability to quickly adapt to new conditions and other qualities that determine the competitiveness of an individual (Ivanenko et al., 2015).

In this regard, even more relevant becomes the task of strengthening the focus of the educational process on the professional's competitiveness formation. Obvious has become the fact that a competitive specialist can be trained only by a competitive teacher - a person responsible for education, training and development of the oncoming generation. This fact has predetermined the appearance of teachers' competitiveness formation problem in educational theory and practice (Andreev, 2004; Bodyan, 2009; Masalimova \& Shaidullin, 2006; Ansoff, 2009).

The state is interested in forming competitiveness of teachers of both higher and secondary vocational education institutions; as it is associated with solving the problems of training future competitive specialists for innovative production, increase of the organizations' and institutions' social efficiency performance, economic recovery of the country.

However, in the documents on education, the state standards, including those for teaching professions, the 
concept of "competitiveness" has not been reflected enough. This is due to lack of theoretical elaboration of this problem.

\section{Literature Review}

In academic literature there is a sufficient amount of research devoted to the development of a model to form competitiveness of professionals, students, and future teachers. However, there are no studies devoted to the development of models to form competitiveness of teaching staff. Consequently, on developing a model as part of our research it is necessary to draw on the existing studies, which reveal the nature and content of the modeling process.

The works of many scientists are dedicated to the review of structural components of a model for forming a specialist's competitiveness: Angelovsky (2004), Bodyan (2009), Dushkina (2001) and others.

O. V. Dushkina, for example, explores the targeted, activity-based, and efficiency control components, as well as components that reflect the professional orientation, knowledge, abilities, skills and professional strengths (Dushkina, 2001).

A. A. Angelovsky, when analyzing the process of forming competitiveness of university students as a complex, multi-level educational system, names the purpose, content, methods, and organizational forms and results as the main components (Angelovsky, 2004).

The structurally-functional model to form competitiveness of university students is seen by A. A. Angelovsky as a complex, holistic and multi-level dynamic system comprising such interconnected clusters as: educational and organizational activities, as well as activities for forming and developing personal qualities of a competitive specialist (Angelovsky, 2004).

The model to form competitiveness of graduates, determined by the specificity of their professional training, was studied by L. D. Bodyan, who elaborated and tested a structurally-functional model to develop competitiveness of technical university students. In this model there are: structurally-targeted, functional, methodical (organizational), and content-productive clusters (Bodyan, 2009). This model is based on the principles of context-modular approach; it helps motivate personal and professional activity, as well as actualize permanent self-development and self-realization of technical university students.

T. Yu. Melnichenko emphasizes the basic elements of a model to form competitiveness of Education Department students: supporting and newly acquired economic knowledge of the future specialist, reproductive and creative practice methods in the study of the socio-cultural unit of general education; creative skills and techniques of the future specialists to restructure the educational material for the formation of their competitiveness; stages and levels of acquiring the appropriate economic knowledge, aimed at developing the professional abilities for competitiveness; methods of action and practical readiness of students to elaborate their competitiveness (Melnichenko, 2004).

Presenting a model to form a competitive specialist in professionally-ecological education, R. A. Krivtsov classifies its components into three functionally interrelated levels: axiological, which is reducible to the formation of the student's personal position on his future professionally-ecological activities; ontological, including modular content; technological, which determines the willingness of students to learn, technological organization of the learning process, pedagogical conditions of effective training a competitive professional demanded in the labor market (Krivtsov, 2008).

Commonality of groups to form competitiveness in professional training of graduates was considered by V. I. Andreev. In his developed "ideal model" of a competitive person the attention is drawn to the following professionally and socially important personal qualities: a group of motives and values, moral and civic qualities, intellectual and business qualities, character and behavior features, communication skills, organizational skills, "self" abilities and "self" processes (2004).

Considering the process of forming personal competitiveness of a future teacher of vocational training as a complex, multi-level educational system E. V. Evplova defines in it such structural components as the goal, content, organization and result. The identified components are defined by the targeted, substantive, organizational and productivity clusters, each of which she designates as parts of the model, which is united by means of certain functional relations (2012). The targeted cluster is aimed at implementing the objective function of the model, which provides guidance and motivation of the pedagogical process participants for the formation of their personal competitiveness. As for the goal, it is concretized in tasks for the formation of personal and professional qualities of the future vocational training teachers. The substantive cluster is represented by a set of such components as motivational, activity-based, and reflexive-evaluative. The organizational cluster of the 
model is characterized by integration of various forms, methods and ways to organize the educative process. The productive cluster of her proposed model, which is presented by the low, middle, upper-middle and high levels, reflects the result of personal competitiveness formation process.

V. N. Mezinov proposes a model of a future teacher's competitiveness formation, which aims at determining the theoretical and methodological framework for constructing and managing such process, system of design characteristics, criteria and performance indicators; the priority areas and logically-substantive foundations of integration, common logic and procedures for structuring the educational content, situations, problems and contradictions, which are fundamentally important in mastering competitive behavior (Mezinov, 2008).

A structurally-substantive model of teacher competitiveness is presented by M. V. Mashchenko, which includes the motivational-values component with the reflection of an individual's value systems, formed spiritual and moral qualities, positive attitudes to various kinds of socially significant activities, the need for self-actualization, self-expression, self-assertion, self-development; the system-acmeological, which is about trying to improve themselves, to identify personal perspectives of competitive behavior, self-improve in accordance with the ideal model of a person's competitiveness; the cognitive-reflexive, characterized by mental perception and external information processing ability in the professional field, which reflects knowledge of the main categories, principles and objective laws in teaching activities; the activity-practical, including cognitive, communicative and regulatory abilities and skills which determine the competitive behavior of a successful teacher (Mashchenko, 2011).

\section{Methodological Framework}

Considering the proposed points of view on the component composition of the models to form competitiveness of educational process subjects, in the content of the model within the scope of this research we lay the theoretically-methodological, functionally-targeted, substantive, procedural, methodical and productivity components, the totality of which is aimed at the effective formation of technical college teaching staff competitiveness.

In the basis of modeling the formation of the technical college teaching staff competitiveness within the competence paradigm of vocational training we laid the integrative and milieu approaches.

An integrative approach in forming the competitiveness of college teaching staff is manifested in: integration of educative, methodological and research activities of college teachers; professional interaction of the college teaching staff members; interprofessional collaboration of the college teaching staff with teams of other educational institutions, scientific research institutes, professional community.

The advantage of the integrative approach to form the competitiveness of college teaching staff is that it creates the conditions for continuous interaction of its subjects, both within the team and outside it, where the sign of productivity of their integration will be not so much the density of these relations, as integrative integrity.

The major structural element of the integrated team internal structure is the personality having the purposefulness of its behavior and tending to its own "self-completion" through integrative relations with the external environment, where its competitive properties, being specific system properties, can not only complete themselves, but also by their contribution transfer the entire system to a whole new level (Ivanov et al., 2015; Shaidullina \& Ivanenko, 2012).

Any real pedagogical object contains internal contradictions, which can be understood as pairs of antagonisms, the harmonization of which involves unity and mutual transitions of these polarities that reflect their dynamic balance. In this regard, the self-completion of the subsystem should not be identified with the already-formed ways of interaction, and it is necessary to go beyond the system, that is, to the conditions of unstructured situations, as the viability of the subsystem depends on the ability to self-organization, which can only be achieved in the course of this subsystem's independent selection of cooperation areas, allowing to replenish and self-complete themselves.

The need for relying on the milieu approach in forming the competitiveness of the college teaching staff is due to the fact that the milieu approach is focused on creating some positive competitive environment to ensure the efficient formation of the college teaching staff competitiveness. Wherein, the main methodological line remains the formation and development of personality management in the college teaching staff mediated by the corporate environment. The milieu approach in this sense can be considered as the methodology for obtaining a mass result —of socially significant corporate purposes.

The corporate college environment, influencing a teacher's lifestyle, specifies the models of life in a teaching team, typifying it and allowing the team members to put into practice certain ideals and receive a particular type 
of personality through its corporate interaction. The positive point is that the individuality and uniqueness of a teacher in this case do not suffer, because the field of displaying the individual style remains wide enough for the teacher.

The concept of the milieu approach is based on such humanistic areas as synergetics, phenomenology, existentialism, hermeneutics, and allows relying on the boundless potentiality of the college teaching staff members as a factor to increase their competitiveness. In this regard, the milieu approach allows predicting the possibilities for the corporate environment of the teacher training college, designing environment-formative niches and planning measures for their implementation to generate the competitive environment, which forms the competitiveness of the teaching staff as a whole.

In the basis of modeling the formation of the teaching staff competitiveness there are the following principles: the dialogic principle, involving reflexive dialogue of the teaching staff members for the effective interchange of the existing potential for forecasting and solving the strategic problems of the college; the principle of transparency, implying openness and accessibility of the teaching staff members' achievements, in order to maintain a competitive environment; the corporativity principle, implying solidarity in professional goals and values of the teaching staff members to implement joint professional activity for enhancing the effectiveness of the college educational process; the principle of dynamism, involving continuous development, self-development and improvement of the teaching staff members in order to maintain competitive advantages of the college in general for its adaptation to the changing socio-economic conditions.

\section{Results}

As the purpose of the modeling, the formation of the college teaching staff competitiveness was indicated.

The objectives of the college teaching staff competitiveness formation are the following:

- Formation of corporate competency of the college teaching staff members;

- Integration of educative, methodological and research activities of college teachers;

-Creation of a continuous system of training, retraining and professional development of college teachers;

- Organization of a mentoring system in college;

- Systematic diagnostics and correction of the college teaching staff competitiveness formation levels.

In the content of the teaching staff competitiveness, we are laying the personal, professional and inter-professional components of its formation:

1)The personal component of the teaching staff competitiveness formation is characterized by commitment and confidence of its members in their abilities; leadership qualities; pursuance of innovation; skills of self-education and professional development; initiative and self-discipline; entrepreneurial spirit and businesslike character; self-analysis and nonstandard decision-making abilities; self-presentation ability; personal responsibility for the results of the performed work; ability to take risks and protect their rights and freedoms; emotional stability and communication skills.

2)The professional component of the teaching staff competitiveness formation is characterized by professional competence, professional excellence of its members and the quality of work; ability to adequately assess personal professional opportunities; ability to navigate in the rules and ethics of labor relations; understanding the goals and objectives of professional activity; ability to flexibly and quickly apply knowledge and experience to solve practical problems; ability to formulate current and final professional goals and objectives; ability to find forms and ways to solve professional problems; ability to adapt to new situations; ability to create strategies for professional activities; ability to apply innovative technologies in their subject area; ability to use information in the field of professional knowledge.

3)The inter-professional component of the teaching staff competitiveness formation has a high level of general education and culture of its members; general informational, educational, general technical, computer, economic, legal, psychological training in combination with deep narrow-professional, single-discipline knowledge; ability to make common decisions, anticipate their possible economic and social outcome, and be responsible for the decisions taken and the results of joint activities; social and occupational mobility, communication skills; ability to resolve conflict situations; ability to maintain broad, active and diverse creative contacts on scientific, professional and educational activities issues.

The presented components of forming the college teaching staff competitiveness are directed both to the formation of stable, highly professional, creative teaching staff, and to every teacher's acquisition of new 
information and teacher education technologies.

In order to effectively form the competitiveness of the teaching staff we have proposed an algorithm for the process, which includes three stages:

- The informational-reproductive stage, involving formation of cognitive basis of the teaching staff members' competitive consciousness and behavior. This stage is characterized by the fact that college teachers tend to learn modern methods in teaching and research activities, develop missing qualities, for what they are engaged in constant professional self-instruction and self-education. However, at this stage of the teaching staff competitiveness formation there are contradictions in their team work, more notably the competition with each other is seen, which limits the possibilities of large-scale educational college projects joint development;

- The actively-search stage, involving development and intensification of competitive consciousness and behavior of the teaching staff members. This stage is characterized by sustained creative attitude towards work in a team. However, at the implementation of joint activities phase there are other particular problems and contradictions related to the fact that according to his/her competence development level a teacher may be ahead of some of his/her colleagues, and the teacher's striving for innovative reforms encounters external misunderstanding and even resistance;

- The intensively-creative stage, involving improvement and implementation of the competitive behavior of the teaching staff members in diverse situations. This stage is characterized by flexible and dynamic behavior of the teaching staff members in accordance with the changing educational situation in the society, the imposed new requirements on the teacher and college in general. At this stage, with the joint development of various projects, teachers feel responsibility not only on their part, but for the whole project.

The set of the proposed stages of forming competitiveness of college teaching staff aims at ensuring flexible use of the existing knowledge and skills of the teaching staff members for joint solutions of complex educational problems, innovative activity of teachers, which is shown in the search and creative use of new didactic technologies, copyright study aids, in the study of related sciences, innovative experience, project and research activities.

\section{Conclusion}

The proposed structurally-functional model of forming college teaching staff competitiveness includes the following components:

- Theoretically-methodological, submitted by justification of the integrative and milieu approaches; definition of principles: dialogic, corporativity, transparency and dynamism;

- Functionally-targeted, comprising a target (raising and maintaining the competitiveness of the college in the education market) and problems (formation of corporate competence of college teaching staff members, integration of educational, methodological and research activities of college teachers; creation of a continuous system of training, retraining and professional development of college teachers; college mentoring system organization; systematic diagnostics and correction of the college teaching staff competitiveness formation levels);

- Substantive, presented by a set of personal, professional and interprofessional components of the teaching staff competitiveness;

- Technological, involving a set of stages to form competitiveness of technical college teaching staff: informationally-reproductive, actively-search, intensively-creative;

- Productive, which includes criteria of technical college teaching staff competitiveness formation (motivational, cognitive, and activity-based) and their performance indicators.

\section{References}

Andreev, V. I. (2004). Konkurentology. In Training course for creative self-development of competitiveness. Kazan.

Angelovsky, A. A. (2004). Formation of competitiveness of students in the course of vocational training in high school (PhD Thesis). Magnitogorsk.

Ansoff, I. (2009). Strategic Management. Saint Petersburg.

Bodyan, L. A. (2009). Development of the competitiveness of a technical college students on the basis of context-modular approach (PhD Thesis). Magnitogorsk. 
Dushkin, O. V. (2001). Formation of competitiveness of students of secondary specialized educational institutions of trade and economic profile ( $\mathrm{PhD}$ Thesis). Lipetsk.

Evplova, E. V. (2012). Guidelines for the formation of competitiveness of the future teachers of vocational training. Chelyabinsk.

Ivanenko, N. A., Khairova, I. V., Fajzrakhmanova, A. L., Khalilova, T. V., Kharisova, G. M., Lisitzina, T. B., \& Shaimukhametova, S .F. (2015). Competitiveness of Professional Education: Purposes, Tasks and Factors of Its Participation in the International Educational Services Market. Asian Social Science, 11(1), 369-374.

Ivanov, V. G., Shaidullina, A. R., Drovnikov, A. S., Yakovlev, S. A., \& Masalimova, A. R. (2015). Regional Experience of Students' Innovative and Entrepreneurial Competence Forming. Asian Social Science, 11(1), $35-40$.

Krivtsov, R. A. (2008). Formation of the competitive expert in the process of professional environmental education in high school (PhD Thesis). Nizhny Novgorod.

Laslo, E. (1997). Roads leading to the coming millennium. Problems and prospects, Vieta, 4.

Masalimova, A. R., \& Shaidullina, A. R. (2006). Foreign experience of integration of research, teaching and practice of students of higher technical schools. Kazan pedagogical journal, 5, 54-61.

Mashchenko, M. V. (2011). The model of formation of competitiveness teacher in pedagogical high school. Actual questions the use of innovative technologies in the educational process. Nizhny Tagil: NTGSPA.

Melnichenko, T. Y. (2004). Formation of competitiveness of the future expert in the study of economics ( $\mathrm{PhD}$ Thesis). Kaluga.

Mezinov, V. N. (2008). Formation of competitiveness of the future teacher in the process of teacher education (p. 3). Bulletin of Tomsk State Pedagogical University.

Milgram, S. (2001).Experiment in social psychology. Peter.

Shaidullina, A. R. (2009). Preparation of technical specialists in the integration of education and production: Regional Experience. Kazan.

Shaidullina, A. R., \& Ivanenko, N. A. (2012). Mechanisms for the preparation and selection of future competitive technical specialists.Professional education in Russia and abroad, 3(7).

Vladislavlev, A. P. (1978). Continuing education as a method of forming a fully developed personality. Philosophical Sciences, 5.

\section{Copyrights}

Copyright for this article is retained by the author(s), with first publication rights granted to the journal. This is an open-access article distributed under the terms and conditions of the Creative Commons Attribution license (http://creativecommons.org/licenses/by/3.0/). 